\title{
Determinants of late antenatal care follow up among pregnant women in Easter zone Tigray, Northern Ethiopia, 2018: unmatched case-control study
}

\author{
Gebrehiwot Gebremariam Weldearegawi ${ }^{*}$, Berhane Fseha Teklehaimanot ${ }^{1}$, Hirut Teame Gebru', \\ Znabu Asfaw Gebrezgi ${ }^{1}$, Kidanemaryam Berhe Tekola² and Mulu Ftiwi Baraki ${ }^{3}$
}

\begin{abstract}
Objective: The purpose of the study was to identify determinants of late antennal care at first visit in health facilities of eastern zone of Tigray, Northern Ethiopia 2018.

Result: Women with unplanned pregnancy (AOR $=4.03,95 \%, \mathrm{Cl} 1.56-5.67)$, Participants whose previous first antenatal care was after 16 weeks (AOR $=3.9,95 \% \mathrm{Cl} 1.98-7.68)$, Participants did not accompanied by their partner for antenatal visit (AOR $=1.29,95 \%, \mathrm{Cl} 1.05-4.67)$, women recognized their current pregnancy at 3 months or late (AOR=4.7, 95\%, Cl 2.49-9.04) and participants provided adequate time for their previous antenatal care by health professionals $(A O R=0.461,95 \% \mathrm{Cl} 0.342-0.875)$ were found the determinant factors of late antenatal care at first Visit. Hence family planning utilization, times of first visit antenatal, information flow and supporting by partners have a great role in improving antenatal care at first visit. There for responsible bodies should give focuses on utilization of family planning, increasing awareness of pregnancy symptoms and health provisional provide adequate time during visits.
\end{abstract}

Keywords: Late, Antenatal, Eastern zone, Tigray, Ethiopia

\section{Introduction}

Maternal mortality due to complications of child birth in sub Saharan African countries is the highest, which accounts about $66 \%$ from the total mortality in the globe [1]. Evidences showed the most common causes of maternal mortalities can be prevented through quality of ANC (antenatal care) [2]. Therefore the World Health Organization recommended all pregnant women should provide the focused ANC services within the first trimester of pregnancy, that enables them with a number of interventions important for themselves and their infants [2, 3]. Similarly of quality ANC is recognized as an important opportunity for screening and early identification of complications such as pre-eclampsia, anaemia,

\footnotetext{
*Correspondence: geregg6@gmail.com; gebrihet@gmail.com 1 Department of Public Health, College of Medicine and Health Sciences, Adigrat University, Adigrat, Ethiopia

Full list of author information is available at the end of the article
}

and gestational diabetes [4]. However pregnant women who provided poor quality, attended less and late first visit were associated with an increased risks of stillbirth [5]. Although, the focused ANC model recommends all pregnant woman need to start first visit of ANC in the first trimester of pregnancy, a significant proportion of women from developing countries including Ethiopia did not start ANC according to the recommendation [6, 7].

In the other hand, despite the fact that pregnant women in most of the developing countries attended first $\mathrm{ANC}$ at a late time, but it plays a significant role in timely management and treatment of complications to reduces maternal morbidity and mortalities during antepartum, intra partum and post-partum period and a good basis for appropriate management for delivery and after childbirth if they attended early [8]. However, in case of delay attending it resulted with different problems during pregnancy, delivery, and puerperium periods $[4,6]$. 
Though a study done in south Africa, indicated there was no effect of gestational age at first ANC visit on stillbirth outcomes [9], but evidence from New Zealand and south Africa implied late attending of ANC was highly related with still birth $[5,10]$. To alleviate the problems related with attending late ANC at first visit, the Federal Ministry Health of Ethiopia is trying to implement the WHO recombination focused ANC model, but many studied in the country indicated only about one-third of pregnant women were attending first ANC before the first 4 months of pregnancy [2, $7,8,11]$. In addition, even though there are few evidences on the timing of antenatal care in Ethiopia, but the evidences did not addressed the determinants of early antenatal care visit in the country. Hence this study had identified the determinates of late antenatal care among pregnant women who were attending ANC in health facilities of Eastern Zone of Tigray regional state, North Ethiopia 2018.

\section{Main text \\ Methods \\ Study setting and design}

The study was done in eastern zone of Tigray regional state, North Ethiopia which was financially funded by Adigrat University with registration number of AGU/ CMHS/033/10. Unmatched case-control study design was employed to generalized the determinates of late ANC for all age groups, residences and other related issues from January 2018 to April 2018. Time of first ANC attendance was considered as an outcome variable. Participants were categorized as cases and controls based their time of first ANC as an outcome variable to identify the determinants of late ANC due to the fact that the WHO recommends pregnant women need to start ANC first visit with in the first trimester (in the first 4 months), second visit 20-24 weeks, third visit 28-32 weeks and fourth visit at 36 weeks or after. Accordingly, Participants who visited first ANC after 16 weeks of gestation were considered as cases and participants attended first visit of ANC within the first 16 weeks were considered as controls. All pregnant women who were doing their schedule of first visit in all of the health facilities were included as sources of population. However pregnant women who were severely ill and mentally ill during the data collection were excluded due to they might not give appropriate information.

\section{Sampling size and techniques}

Sample size was calculated using EPI INFO Version 7 by considering proportion of mothers who had good knowledge on advantage of early ANC among cases was 58.2\% (main exposure variable with $\mathrm{AOR}=2.1$ ) from previous study done in Ethiopia [7]. In addition 95\% CI, 80\% power and 1:1 control to case ratio was taken. Accordingly by adding $10 \%$ none response rate the final sample size was 201 cases and 201 controls (total of 402 participants). To obtain the required sample size 12 health facilities were selected randomly from the total 44 health facilities of the Zone. Thus, eligible Participants were shared proportionally to population size of each health facilities. Finally participants were selected using systematic sampling technique from the total pregnant mothers attending ANC first visit in the selected health facilities.

\section{Data collection tools and analysis}

The determinants of late ANC was assessed using structured and pre tested questionnaires by face to face interview. Questionnaires were developed in English, and then it was translated to local language to check its completeness, consistence, accuracy and finally applied the English version. The actual data was collected during their first ANC visit. Twelve Midwifery professional data collectors and three Bachelor of Science in Nursing Supervisors were recruited. Two days training was given for data collectors and supervisors. The preliminary data was coded and checked for completeness, consistent and managed accordingly. Data clean up and cross-checking was also done before the analysis. Data was entered to SPSS version 20 for analysis. Cross tabulation was done to see the distribution of cases and controls by frequency, percentage and mean. Bivariate and multivariate logistic regression was done. Each variable with the outcome of interest at $\mathrm{p}<0.05$ in the bivariate analysis was transported to multivariable analysis. Each independent variable at $\mathrm{p}<0.05$ was declared as determinate factors in the final model. Multi-collinearity using VIF (Variance Inflator Factor) at the cut of point 10 and Model goodness of fit using Hosmer-Lemeshow test at $p$ value $>0.05$ was done. The overall design, data collection and analysis was followed and checked by the funding agency (Adigrat University). Finally the finding of the study was presented to Adigrat University and respected districts.

\section{Result}

\section{Part I: Socio demographic characteristics and obstetric history of participants}

In the current study, 199 controls and 199 cases were participated making a response rate of $98.7 \%$. Majority, 54 (27.1\%) control and $53(26.6 \%)$ case were in the age group of 25-29 years with the mean age of 27 years $(\mathrm{SD} \pm 6.3)$. The highest 113 (56.8) controls and 109 (54.8) case were house wives. Only 19 (9.5\%) controls and 15 (6.5\%) case were governmental employed. In educational status, the highest $89(44.7 \%)$ controls and $72(36.1 \%)$ cases were attended 7-10 grade (Table 1). 
Most of the participants, 67 (49.6\%) controls and 58 (35.4\%) cases had 2-4 births. Regarding the number of alive children they had, 69 (53.1\%) controls and 77 (47\%) cases had 1-2 alive children, and 25 (21.2\%) controls and $29(18.8 \%)$ cases had history of abortion. Out of the total participants 53 (26.6\%) controls and 84 (42.4\%) controls their current pregnancy were unplanned. Concerning the time of previous ANC follow up, 35 (53.3\%) controls and $71(51.1 \%)$ case were attended after 16 weeks. Participants were asked if they know when ANC visit will be started, accordingly, 42 (21. 1\%) controls and 116 (58.3\%) case replied it should start after 16 weeks (Table 2).

\section{Part II: Determinates of late ANC among pregnant women in Eastern Tigray, North Ethiopia}

The current study identified pregnancy status, Time of previous ANC attendance, accompanied by their partner for $\mathrm{ANC}$, time of recognized their pregnancy and provided adequate time for their previous ANC by health professionals were found the determinates of Late ANC follow up. Participants whose pregnancy was unplanned were 4 times more likely attending late $(\mathrm{AOR}=4.03$, 95\% CI 1.56-5.67). Women whose previous first ANC was after 16 weeks were 3.9 times attended late compared to those whose previous ANC was before 16 weeks $(\mathrm{AOR}=3.9,95 \% \mathrm{CI} 1.98-7.68)$. Pregnant who recognized their pregnancy after the first 3 months were 4.7 times attending late as compared with those who recognized with in the first 2 months (AOR $=4.75,95 \%$, CI 1.495 9.042). However participants who provided adequate time for their previous ANC visit by health professionals were about $53 \%$ attending early compared to those who did not provided adequate time (AOR $=0.461,95 \% \mathrm{CI}$ 0.342-0.875) (Table 3).

The current study revealed that women with unplanned pregnancy were 4 times more likely attending late compared to women their pregnancy was planned. Similar finding was shared from studies in Arbaminch and Addis Ababa, Ethiopia [6, 12]. Bayou et al., also reported intention of pregnancy was found as a predictor of late ANC [13]. Another study in South western Ethiopia explained, late attendance of ANC was higher among women with unplanned pregnancy [14]. An evidenced from South Africa and Kenya indicated, unplanned pregnancy was an independent determinant factor for late ANC $[10,15]$. This could be due to pregnant women with unplanned pregnancies might miss supports from partner or family, so they might not recognized their pregnancy early. In contrary if they recognized their pregnancy early, they can alert about the disadvantage attending late and they may give more care for their pregnancy themselves and from spouses.
We found women who attended ANC first after 16 weeks for past pregnancy was showed significant determinant for late attending. Similarly, Girmatsion et al. stated women who attended early ANC for past pregnancy were less likely to start late compared to those attended late for the past pregnancy [7]. This might be the fact that women who attended ANC with in the first 4 months for the past pregnancy are expected to have better awareness on the advantage of early ANC visit. In addition, the odds of late ANC among women who did not accompanied by their partner were 1.2 times higher than those who accompanied. Similar report was observed in a study done in Tanzania [16] and in Ethiopia [12].

Again the odds of late ANC at first visit were 1.2 times higher among women who gave birth 2-4 children than primigravida. Tolefac et al. reported, the odds of late ANC were high among women who had $\geq 4$ children [17]. Manzi et al. and Ochako et al. also share similar finding $[15,18]$. The same evidence was also shared from a study done in Bhutan [19]. Ideally, as the size of children increases, the likelihood of attending ANC visit early will be dropped. It might be due to in developing countries especially in Ethiopia mothers are responsible and preoccupied in routing house hold activities and giving care for their kids, so they may get difficult in representing another person who gives care for the kids and the house hold activities. This evidence was confirmed by time constraint with household activity was one of the main reason for late ANC in Ethiopia [11]. In the other hand the current study identified women who recognized their pregnancy at third months or late were attending late than those who recognized their pregnancy before 3 months. This finding was supported by a study done in south eastern Tanzania [16].

Hence, the study identified women need to have planned pregnancy, they should recognized their pregnancy early and the health providers should give them adequate time. Tigray regional health bureau and the respective health facilities in collaboration with other stake holders should give due emphasis on community awareness in family planning, sign and symptoms of pregnancy.

\section{Limitation}

The study was case-control study that did not address the outcomes of late attending of ANC first visit, so it will be a focus for future researchable area.

\section{Abbreviations}

AGU: Adigrat University; ANC: ante natal care; AOR: adjusted odds ratio; Cl: confidence interval; CMHS: College of Medicine and Health Sciences; SD: 
standard deviation; SPSS: Statistical Package for Social Sciences; WHO: World Health Organization.

\section{Acknowledgements}

First of all we would like to acknowledge Adigrat University College of Health Science for giving us this chance and funding the study. Secondly we are greatly indebted to each health facilities for gave us indispensible information. Lastly our great deepest gratitude also goes to study participants for their time and participated fully.

\section{Authors' contributions}

GG initiated the idea and wrote the proposal, participated in data collection supervisor, literature review, in designing analysis and report writing. KB involved in designing, analysis and report writing. BF involved in designing, questionnaires preparation and analysis. HT participated in report writing and manuscript preparation. MF, contributed in supervisor and report writing. ZA contributing in report writing and manuscript editing. All authors read and approved the final manuscript.

\section{Funding}

The research was Funded by Adigrat University with the Registration Number of AGU/CMHS/033/10. The funding obtained from Adigrat University was mainly for data collection, analysis and interpretation (presentation) purposes of the findings.

\section{Availability of data and materials}

All data pertaining to this study is attached its description in the annex part at the final document and the data set has been attached in the Journal manuscript tracking system as supporting file coded as "0"for controls and "1" for cases with the file name clean data.

\section{Ethics approval and consent to participate}

Ethical clearance was secured from Adigrat University ethical review board and provided a Registration Number of AGU/CMHS/033/10. Written permission was obtained from Tigray Regional health bureau and each respective district health offices. Written permission was also obtained from each study participants. Consent for participation for those who were teenagers was obtained from their relatives. The participants were told about the aim of the study and they have informed also about the information they provided will be kept confidential as the data would be used only for the purpose of generating new information. They were also told they have the right to refuse the interview even in the midterm of the interview if they are incontinent.

\section{Consent of publication}

Not applicable.

\section{Competing of interests}

The authors declared that they have no competing interests.

\section{Author details}

${ }^{1}$ Department of Public Health, College of Medicine and Health Sciences, Adigrat University, Adigrat, Ethiopia. ${ }^{2}$ School of Public Health, Department of Nutrition, Mekelle University, Mek'ele, Ethiopia. ${ }^{3}$ Department of Midwifery, College of Medicine and Health Sciences, Adigrat University, Adigrat, Ethiopia.

\section{Appendix}

See Tables 1, 2 and 3. 
Table 1 Socio demographic and economic characteristics of pregnant mothers attending antenatal care follow up Easter Zone Tigray, 2018

\begin{tabular}{|c|c|c|c|c|c|}
\hline S. no & Variables & Characteristics & $\begin{array}{l}\text { Before or at } 16 \text { weeks } \\
(n=199) \text { controls }\end{array}$ & $\begin{array}{l}\text { After } 16 \text { weeks } \\
(\mathrm{N}=199) \\
\text { Case }\end{array}$ & Total \\
\hline \multirow[t]{5}{*}{1} & Age & $<19$ years old & $15(7.5)$ & $18(9)$ & 33 \\
\hline & & 20-24 years old & $72(36.2$ & $47(23.6)$ & 119 \\
\hline & & 25-29 years old & $54(27.1)$ & $53(26.6)$ & 107 \\
\hline & & 30-34 years old & $32(16.1)$ & $55(27.6)$ & 87 \\
\hline & & $\geq 35$ years old & $26(13.1)$ & $26(13.1)$ & 52 \\
\hline \multirow[t]{3}{*}{2} & Marital status & Married & $176(88.4)$ & $169(84.9)$ & 345 \\
\hline & & Single & $17(8.5)$ & $20(10.1)$ & 37 \\
\hline & & Divorced & $3(1.5)$ & $10(4.5)$ & 13 \\
\hline \multirow[t]{2}{*}{3} & Religion & Orthodox & $167(83.9)$ & $163(81.9)$ & 330 \\
\hline & & Muslim & $36(18.1)$ & $33(16.6)$ & 68 \\
\hline \multirow[t]{4}{*}{4} & Ethnic group & Tigrian & $175(87.9)$ & $179(89.9)$ & 354 \\
\hline & & Amhara & $8(4)$ & $6(3)$ & 14 \\
\hline & & Oromo & $6(3)$ & $7(3.5)$ & 13 \\
\hline & & Others (Afar and SNNP) & $6(3)$ & $7(3.5)$ & 13 \\
\hline \multirow[t]{6}{*}{5} & Occupational status & Governmental employed & $19(9.5)$ & $15(6.5)$ & 34 \\
\hline & & Student & $18(9)$ & $22(11.1)$ & 40 \\
\hline & & Housewife/farmer & $109(54.8)$ & $113(56.8)$ & 222 \\
\hline & & Merchant & $14(7)$ & $15(7.5)$ & 19 \\
\hline & & Private company & $36(18.1)$ & $29(14.6)$ & 65 \\
\hline & & Others & $5(2.5)$ & $3(1.5)$ & 8 \\
\hline \multirow[t]{6}{*}{6} & Husband occupation & Governmental employed & $33(16.6)$ & $31(15.6)$ & 64 \\
\hline & & NGO and students & $17(8.5)$ & $9(4.5)$ & 26 \\
\hline & & Farmer & $34(17.1)$ & $41(20.6)$ & 75 \\
\hline & & Merchant & $51(25.6)$ & 49 (24.6) & 100 \\
\hline & & Private employed & $51(20.7)$ & $53(26.5)$ & 104 \\
\hline & & Daily laborer & $13(6.5)$ & $16(8.2)$ & 29 \\
\hline \multirow[t]{6}{*}{7} & Educational status & Illiterate & $36(16.1)$ & $54(27.1)$ & 90 \\
\hline & & Can read and write & $10(5)$ & $14(79)$ & 24 \\
\hline & & $1-6$ grade & $33(16.6)$ & $34(17.10)$ & 67 \\
\hline & & $7-10$ grade & $89(44.7)$ & $72(36.1)$ & 161 \\
\hline & & Preparatory completed & $9(4.5)$ & $9(4.5)$ & 18 \\
\hline & & Diploma and above & $22(11.1)$ & $16(8)$ & 38 \\
\hline \multirow[t]{6}{*}{8} & Husband educational level & Illiterate & $12(6)$ & $34(17.1)$ & 46 \\
\hline & & Can read and write & $18(9)$ & $28(14.1)$ & 46 \\
\hline & & $1-6$ grade & $36(18.1)$ & $25(12.6)$ & 61 \\
\hline & & 7-10 grade & $76(38.2 \%)$ & $71(35.7)$ & 147 \\
\hline & & Preparatory completed & $13(6.5)$ & $13(6.5)$ & 26 \\
\hline & & Diploma and above & $44(22.1)$ & $28(14.1)$ & 72 \\
\hline \multirow[t]{2}{*}{9} & Residence & Urban & $124(62.3)$ & $95(47.7)$ & 219 \\
\hline & & Rural & $75(37.7)$ & $104(52.8)$ & 179 \\
\hline \multirow[t]{2}{*}{10} & Year of marriage & $<18$ years & $71(35.7)$ & $88(44.2)$ & 159 \\
\hline & & $\geq 18$ years & $128(64.3)$ & $111(55.8)$ & 249 \\
\hline \multirow[t]{2}{*}{11} & Year of first birth $(n=271)$ & $\leq 19$ years & $56(47.9)$ & $87(56.5)$ & 143 \\
\hline & & $\geq 20$ years & $61(52.1)$ & $67(43.5)$ & 128 \\
\hline
\end{tabular}


Table 2 Obstetric history and utilization of pregnant mothers attending antenatal care follow up in Easter zone of Tigray, 2019

\begin{tabular}{|c|c|c|c|c|c|}
\hline S. no. & Characteristics & Responses & $\begin{array}{l}\text { Before } \\
\text { or at } 16 \text { weeks } \\
(n=199)\end{array}$ & $\begin{array}{l}\text { After } 16 \text { weeks } \\
(\mathrm{N}=199)\end{array}$ & Total \\
\hline \multirow[t]{3}{*}{1} & \multirow[t]{3}{*}{ Total no of pregnancy } & Only one & $82(41.2)$ & $45(22.6)$ & 127 \\
\hline & & 2-4 times & $89(44.7)$ & $105(52.8)$ & 194 \\
\hline & & 5 and more & $28(14.1)$ & $49(24.6)$ & 77 \\
\hline \multirow[t]{3}{*}{2} & \multirow[t]{3}{*}{ Total no of births } & Only one & $67(49.6)$ & $58(35.4)$ & 125 \\
\hline & & $2-4$ births & $67(49.6)$ & $58(35.4)$ & 125 \\
\hline & & 5 and more births & $15(11.1)$ & $26(15.9)$ & 41 \\
\hline \multirow[t]{3}{*}{3} & \multirow[t]{3}{*}{ Total alive births } & No alive birth & $28(21.5)$ & $15(9.1)$ & 43 \\
\hline & & $1-2$ alive births & $69(53.1)$ & $77(47)$ & 146 \\
\hline & & $\geq 3$ and above alive births & $33(25.4)$ & $72(43.9)$ & 105 \\
\hline \multirow[t]{3}{*}{4} & \multirow[t]{3}{*}{ Total no of live children } & No alive child & $28(21.5)$ & $15(9.1)$ & 43 \\
\hline & & 1-2 live children & $69(53.1)$ & $77(47)$ & 146 \\
\hline & & 3 and more alive children & $33(25.4)$ & $72(43.9)$ & 105 \\
\hline \multirow[t]{2}{*}{5} & \multirow[t]{2}{*}{ Ever had still birth } & Yes & $19(16.4)$ & $24(15.6)$ & 43 \\
\hline & & No & 97 (83.6) & $130(84.4)$ & 227 \\
\hline \multirow[t]{2}{*}{6} & \multirow[t]{2}{*}{ History of abortion } & Yes & $25(21.2)$ & $29(18.8)$ & 54 \\
\hline & & No & $93(78.8)$ & $12(581.2)$ & 218 \\
\hline \multirow[t]{2}{*}{7} & \multirow[t]{2}{*}{ Current pregnancy } & Planned & $146(73.4)$ & $114(57.3)$ & 260 \\
\hline & & Unplanned & $53(26.6)$ & $84(42.2)$ & 137 \\
\hline \multirow[t]{3}{*}{8} & \multirow[t]{3}{*}{ Gravidity } & $1 \mathrm{st}$ & $83(41.9)$ & $46(23)$ & 129 \\
\hline & & 2nd & $42(21.2)$ & $47(23.5)$ & 89 \\
\hline & & 3rd and above & $73(36.9)$ & $107(53.5)$ & 180 \\
\hline \multirow[t]{3}{*}{9} & \multirow[t]{3}{*}{ History of ANC follow up for the previous pregnancy } & Yes & $103(52)$ & $138(69)$ & 241 \\
\hline & & No & $11(5.6)$ & $16(8)$ & 27 \\
\hline & & Never pregnant & $84(42.4)$ & $46(23)$ & 130 \\
\hline \multirow[t]{3}{*}{10} & \multirow[t]{3}{*}{ Time of first ANC for previous pregnancy } & Before or 16 weeks & $53(50.5)$ & $37(26.6)$ & 90 \\
\hline & & After 16 weeks & $35(33.3)$ & $71(51.1)$ & 106 \\
\hline & & I did not remember & $17(16.2)$ & $31(22.3)$ & 48 \\
\hline \multirow[t]{5}{*}{11} & \multirow[t]{5}{*}{ No of ANC for previous pregnancy } & Only one & $9(8.3 \%)$ & $7(5.1)$ & 16 \\
\hline & & Two times & $15(13.9)$ & $26(19.1)$ & 41 \\
\hline & & Three times & $28(25.9)$ & $54(39.7)$ & 82 \\
\hline & & Four times & $47(43.5)$ & $36(26.5)$ & 83 \\
\hline & & Above four times & $9(8.3)$ & $13(9.6)$ & 22 \\
\hline \multirow[t]{3}{*}{12} & Know when ANC will start & Before or 16 weeks & $129(64.8)$ & $44(22.1)$ & 173 \\
\hline & & After 16 weeks & $42(21.1)$ & $116(58.3)$ & 158 \\
\hline & & I did not remember & $28(14.1)$ & 39 (19.6) & 67 \\
\hline 13 & Know advantage of ANC & Yes & $185(92.9)$ & $125(72.9)$ & 330 \\
\hline & & No & $34(17.1)$ & $34(17.1)$ & 68 \\
\hline 14 & Know dangers signs of pregnancy & Yes & $128(64.3)$ & $133(66.8)$ & 261 \\
\hline & & No & $71(35.7)$ & $66(33.2)$ & 137 \\
\hline 15 & Types of dangers signs $(n=261)$ & Bleeding & $121(94.2)$ & $109(80.7)$ & 230 \\
\hline & & Sever head ache & $53(41.4)$ & $49(36.3)$ & 102 \\
\hline & & Swelling of extremes & $41(32.2)$ & $38(28.4)$ & 79 \\
\hline & & Convulsion & $41(32.2)$ & $41(30.6)$ & 82 \\
\hline & & Severe abdominal cramping & $29(22.7)$ & $30(22.4)$ & 59 \\
\hline & & Others & $55(42.6)$ & $65(48.1)$ & 120 \\
\hline
\end{tabular}


Table 2 (continued)

\begin{tabular}{|c|c|c|c|c|c|}
\hline S. no. & Characteristics & Responses & $\begin{array}{l}\text { Before } \\
\text { or at } 16 \text { weeks } \\
(n=199)\end{array}$ & $\begin{array}{l}\text { After } 16 \text { weeks } \\
(\mathrm{N}=199)\end{array}$ & Total \\
\hline \multirow[t]{4}{*}{16} & Accompanied by for the previous ANC follow up & Relatives & $32(30.2)$ & $27(20.1)$ & 59 \\
\hline & & My partner & $40(37.7)$ & $42(31.3)$ & 82 \\
\hline & & WDA & $2(1.9)$ & $10(7.5)$ & 12 \\
\hline & & My self & $32(30.2)$ & $55(41)$ & 87 \\
\hline \multirow[t]{2}{*}{17} & Partner encourage for ANC visit & Yes & $167(83.9)$ & $152(76.4)$ & 319 \\
\hline & & No & $32(16.1)$ & $47(23.6)$ & 78 \\
\hline \multirow[t]{2}{*}{18} & Receive inf/n when to start ANC Visit & Yes & $144(72.2)$ & $149(74.9)$ & 293 \\
\hline & & No & $55(27.8)$ & $50(25.1)$ & 105 \\
\hline \multirow[t]{2}{*}{19} & Experienced danger signs for previous pregnancy & Yes & $50(42.4)$ & $47(30.7)$ & 97 \\
\hline & & No & $68(57.6)$ & $106(69.3)$ & 174 \\
\hline \multirow[t]{4}{*}{20} & Means of identifying current pregnancy & Amenorrhea & $74(37.2)$ & $84(42.2)$ & 158 \\
\hline & & HCG test & $104(52.3)$ & $94(47.2)$ & 198 \\
\hline & & Told by Health provider & $15(7.5)$ & $16(8)$ & 31 \\
\hline & & Other & $6(3)$ & $5(2.5)$ & 11 \\
\hline \multirow[t]{5}{*}{21} & Perception of no of ANC visits & Only one & $4(2)$ & $3(1.5)$ & 7 \\
\hline & & Two times & $43(21.6)$ & $48(24.1)$ & 91 \\
\hline & & Three times & $98(49.2)$ & $94(47.2)$ & 19 \\
\hline & & Four times & $54(27.1)$ & $54(27.1)$ & 108 \\
\hline & & More than four times & $4(2)$ & $3(1.5)$ & 7 \\
\hline \multirow[t]{2}{*}{22} & Time of recognized the current pregnancy & $1-2$ months & $129(64.8)$ & $55(27.6)$ & 184 \\
\hline & & After 3 months & $70(35.2)$ & $144(72.4)$ & 211 \\
\hline \multirow[t]{2}{*}{23} & Have HF in your kebelle & Yes & $171(85.9)$ & $181(91)$ & 362 \\
\hline & & No & $28(14.1)$ & $18(9)$ & 36 \\
\hline \multirow[t]{3}{*}{24} & Distance to the nearest health facility & $<60 \min$ & $158(79.4)$ & $141(70.9)$ & 299 \\
\hline & & $60-120 \mathrm{~min}$ & $25(12.6)$ & 27 (13.6) & 52 \\
\hline & & $>120 \mathrm{~min}$ & $16(8 \%)$ & $31(15.6)$ & 47 \\
\hline \multirow[t]{2}{*}{25} & ANC services is provided in comfortable time & Yes & $175(87.9)$ & $177(88.9)$ & 352 \\
\hline & & No & $24(12)$ & $22(11 \%)$ & 46 \\
\hline \multirow[t]{2}{*}{26} & Health provide respectful care & Yes & $167(83.9)$ & $155(77.9)$ & 322 \\
\hline & & No & $32(16.1)$ & $44(22.11)$ & 77 \\
\hline \multirow[t]{2}{*}{27} & Receive in $\mathrm{f} / \mathrm{n}$ about Advantage of ANC & Yes & $179(89.9)$ & $178(89.4)$ & 357 \\
\hline & & No & $20(10.1)$ & $21(10.6)$ & 41 \\
\hline \multirow[t]{6}{*}{28} & Source of information for advantage of ANC & Health providers & $141(77.9)$ & $150(84.2)$ & 290 \\
\hline & & My partner & $23(13.3)$ & $17(9)$ & 40 \\
\hline & & My relatives & $24(13.4)$ & $13(7.3)$ & 37 \\
\hline & & mass media & $51(28.5)$ & $50(28.1)$ & 101 \\
\hline & & Books & $16(8.9)$ & $9(5.1)$ & 25 \\
\hline & & School & $12(8.7)$ & $7(3)$ & 17 \\
\hline \multirow[t]{2}{*}{29} & In which HF had receive ANC for previous pregnancy & Privet & $17(16.3)$ & $19(13.9)$ & 36 \\
\hline & & NGO & $13(12.5)$ & $17(12.4)$ & 30 \\
\hline
\end{tabular}


Table 3 Determinates of late ANC of pregnant mother attending first visit for ANC at Eastern Zone of Tigray. North Ethiopia, 2019

\begin{tabular}{|c|c|c|c|c|c|c|c|}
\hline S. no & Variables & Characteristics & Controls & Cases & COR & AOR & $p$ value \\
\hline \multirow[t]{6}{*}{1.} & \multirow[t]{6}{*}{ Husband occupation } & G. employed & $33(16.6)$ & $31(15.6)$ & $1.036(0.06,0.912)$ & $1.4789(0.334,6.583)$ & 0.606 \\
\hline & & NGO and students & $17(8.5)$ & $9(4.5)$ & $1.143(.024,0.83)$ & $4.682(0.220,9.405)$ & 0.323 \\
\hline & & Farmer & $34(17.1)$ & $41(20.6)$ & $1.301(0.079,1.156)$ & $1.876(0.491,7.161)$ & 0.357 \\
\hline & & Merchant & $51(25.6)$ & $49(24.6)$ & $0.94(0.064,0.903)$ & $1.203(0.324,4.460)$ & 0.783 \\
\hline & & Private employed & $51(20.7)$ & $53(26.5)$ & $1.234(0.063,0.87)$ & $1.532(0.756,3.425)$ & 0.345 \\
\hline & & Daily laborer & $13(6.5)$ & $16(8.2)$ & 1 & 1 & \\
\hline \multirow[t]{2}{*}{2} & \multirow[t]{2}{*}{ Residence } & urban & $124(62.3)$ & $90(45.2)$ & 1 & 1 & \\
\hline & & Rural & $75(37.7)$ & $109(54.8)$ & $1.984(1.329,2.961)$ & $1.697(0.368,1.318)$ & 0.267 \\
\hline \multirow[t]{2}{*}{3} & \multirow[t]{2}{*}{ Current pregnancy status } & Planned & $145(72.9)$ & $95(47.7)$ & 1 & & \\
\hline & & Unplanned & $54(27.1)$ & $104(52.3)$ & $2.940(1.935,4.466)$ & $4.036(1.560,5.671$ & 0.001 \\
\hline \multirow[t]{3}{*}{5} & \multirow[t]{3}{*}{ Time of previous ANC follow up $(n=247)$} & Before or 16 weeks & $65(61.3)$ & $37(26.8)$ & 1 & & \\
\hline & & After 16 weeks & $31(29.2)$ & $71(51.4)$ & $4.024(2.244,7.214)$ & $3.904(1.982,7.688$ & 0.001 \\
\hline & & I did n't remember & $10(9.4)$ & $30(21.7)$ & $5.270(2.317,11.986)$ & $2.892(1.165,7.159)$ & 0.022 \\
\hline \multirow[t]{2}{*}{6} & \multirow[t]{2}{*}{ Partner encourage for ANC visit } & Yes & $160(80.4)$ & $127(63.8)$ & 1 & & \\
\hline & & No & 39 (19.6) & $72(36.2)$ & $2.294(1455,3.614)$ & $1.232(1.051,4.675)$ & 0.047 \\
\hline \multirow[t]{2}{*}{7} & \multirow[t]{2}{*}{ Experience of danger signs } & Yes & $52(44.8)$ & $45(29)$ & 1 & & \\
\hline & & No & $64(55.2)$ & $110(71)$ & $1.986(1.200,2.792)$ & & \\
\hline \multirow[t]{6}{*}{8} & \multirow[t]{3}{*}{ HF provided for pr px } & Privet & $22(11.1)$ & $26(13.1)$ & $1.405(0.187,0.880)$ & $4.036(1.381,11.791)$ & 0.061 \\
\hline & & $\mathrm{NGO}$ & $24(12.1)$ & $10(5)$ & $1.060(0.573,1.9560)$ & $1.649(0.189,2.265)$ & 0.498 \\
\hline & & Governmental & $153(76.9)$ & $163(81.9)$ & 1 & 1 & \\
\hline & \multirow[t]{3}{*}{ Total no of births } & Only one & $67(49.3)$ & $58(35.6)$ & 1 & & \\
\hline & & 2-4 births & $54(39.7)$ & $79(48.5)$ & $1.690(1.032,2.768)$ & $1.145(1.033,3.708)$ & 0.022 \\
\hline & & 5 and more births & $15(11)$ & $26(16)$ & $2.002(0.969,4.139)$ & $1.003(0.296,3.403)$ & 0.987 \\
\hline \multirow[t]{2}{*}{9} & \multirow[t]{2}{*}{ Time of recognize being pregnant } & $1-2$ months & $126(63.3)$ & $59(29.6)$ & 1 & 1 & \\
\hline & & $\geq 3$ months & $73(36.7)$ & $140(70.4)$ & $4.166(2.736,6344)$ & $4.75(2.495,9.042)$ & 0.001 \\
\hline \multirow[t]{3}{*}{10} & \multirow[t]{3}{*}{ Distance to nearest HF } & $<60 \min$ & $159(79.9)$ & $140(70.4)$ & $0.454(0.239,0.866)$ & $1.058(0.336,3.392)$ & 0.924 \\
\hline & & $60-120 \min$ & $24(12.1)$ & $28(14.1)$ & $0.602(0.267,1.358)$ & $0.571(0.151,2.152)$ & 0.408 \\
\hline & & $>120 \min$ & $16(8)$ & $31(15.6)$ & 1 & 1 & \\
\hline \multirow[t]{2}{*}{11} & \multirow{2}{*}{$\begin{array}{l}\text { Adequate time provided for previous } \\
\text { pregnancy }\end{array}$} & Yes & $161(80.9)$ & $150(75.4)$ & $0.327(0.148,0.720)$ & $0.461(0.342,0.875)$ & 0.034 \\
\hline & & No & $38(19.1)$ & 49 (24.6) & 1 & 1 & \\
\hline
\end{tabular}

Received: 2 September 2019 Accepted: 6 November 2019 Published online: 19 November 2019

\section{References}

1. Fekadu A, Yitayal M, Alemayehu GA, Abebe SM, Ayele TA, Tariku A, et al. Frequent Antenatal Care Visits Increase Institutional Delivery at Dabat Health and Demographic Surveillance System Site, Northwest Ethiopia. J Pregnancy. 2019;2019:1690986.

2. Zegeye AM, Bitew BD, Koye DN. Prevalence and determinants of early antenatal care visit among pregnant women attending antenatal care in Debre Berhan Health Institutions, Central Ethiopia. Afr J Reprod Health. 2013;17:130-6

3. Konje ET, Tito M, Magoma N, Hatfield J, Kuhn S, Sauve RS, et al. Missed opportunities in antenatal care for improving the health of pregnant women and newborns in Geita district, Northwest Tanzania. BMC Pregnancy Childbirth. 2018;18(1):394

4. Abejirinde 1O, Douwes R, Bardají A, Abugnaba-abanga R, Zweekhorst M, Van Roosmalen J, et al. Pregnant women's experiences with an integrated diagnostic and decision support device for antenatal care in Ghana. BMC Pregnancy Childbirth. 2018;18:290.
5. Stacey T, Thompson JMD, Mitchell EA, Zuccollo JM, Ekeroma AJ, Mccowan LME. Antenatal care, identification of suboptimal fetal growth and risk of late stillbirth: findings from the Auckland Stillbirth Study. Aust N Z J Obstet Gynaecol. 2012;52:242-7.

6. Gebremeskel F, Dibaba Y, Admassu B. Timing of first antenatal care attendance and associated factors among pregnant women in Arba Minch Town and Arba Minch District, Gamo Gofa Zone, South Ethiopia. J Environ Public Health. 2015;2015:971506.

7. Fisseha G, Miruts G, Tekie M, Michael AW, Yemane D, Gerezigiher T. Predictors of timing of first antenatal care booking at public health centers in Mekelle City, Northern Ethiopia. J Gynecol Obst. 2015;3(3):55-60.

8. Tesfaye G, Loxton D, Chojenta C, Semahegn A, Smith R. Delayed initiation of antenatal care and associated factors in Ethiopia : a systematic review and meta-analysis. Reprod Health. 2017;14(1):150.

9. Beauclair R, Petro G, Myer L. The association between timing of initiation of antenatal care and stillbirths : a retrospective cohort study of pregnant women in Cape Town, South Africa. BMC Pregnancy Childbirth. 2014;14:204.

10. Ebonwu J, Mumbauer A, Uys M, Wainberg ML, Medina-Marino A. Determinants of late antenatal care presentation in rural and periurban communities in South Africa: a cross-sectional study. PLoS ONE. 2018;13(3):e0191903. 
11. Weldemariam S, Damte A, Endris K, Palcon MC, Tesfay K, Berhe A, et al. Late antenatal care initiation: the case of public health centers in Ethiopia. BMC Res Notes. 2018;11:562. https://doi.org/10.1186/s13104-018-3653-6.

12. Gulema $H$, Berhane $Y$. Timing of first antenatal care visit and its associated factors among pregnant women attending public health facilities in Addis Ababa, Ethiopia. Ethiop J Health Sci. 2017;27(2):139-46.

13. Assefa N, Berhane $Y$, Worku A. Wealth status, mid upper arm circumference (MUAC) and antenatal care (ANC) are determinants for low birth weight in Kersa, Ethiopia. PLoS ONE. 2012;7(6):e39957.

14. Terefe AN, Gelaw AB. Determinants of antenatal care visit utilization of child-bearing mothers in Kaffa, Sheka, and Bench Maji Zones of SNNPR, Southwestern Ethiopia. Health Serv Res Manag Epidemiol. 2019. https:// doi.org/10.1177/2333392819866620.

15. Ochako R, Gichuhi W. Pregnancy wantedness, frequency and timing of antenatal care visit among women of childbearing age in Kenya. Reprod Health. 2016. https://doi.org/10.1186/s12978-016-0168-2.

16. Gross K, Alba S, Glass TR, Schellenberg JA, Obrist B. Timing of antenatal care for adolescent and adult pregnant women in south-eastern Tanzania. BMC Pregnancy Childbirth. 2012;12:16
17. Tolefac PN, Halle-ekane GE, Agbor VN, Sama CB, Ngwasiri C, Tebeu PM. Why do pregnant women present late for their first antenatal care consultation in Cameroon? Maternal Health Neonatol Perinatol. 2017;3(1):29.

18. Manzi A, Munyaneza F, Mujawase F, Banamwana L, Sayinzoga F, Thomson $\mathrm{DR}$, et al. Assessing predictors of delayed antenatal care visits in Rwanda: a secondary analysis of Rwanda demographic and health survey 2010. BMC Pregnancy Childbirth. 2014;14:290.

19. Dorji T, Das M, Van Den Bergh R, Oo MM, Gyamtsho S, Tenzin K. "If we miss this chance, it's futile later on" - late antenatal booking and its determinants in Bhutan: a mixed-methods study. BMC Pregnancy Childbirth. 2019. https://doi.org/10.1186/s12884-019-2308-5.

\section{Publisher's Note}

Springer Nature remains neutral with regard to jurisdictional claims in published maps and institutional affiliations.
Ready to submit your research? Choose BMC and benefit from:

- fast, convenient online submission

- thorough peer review by experienced researchers in your field

- rapid publication on acceptance

- support for research data, including large and complex data types

- gold Open Access which fosters wider collaboration and increased citations

- maximum visibility for your research: over $100 \mathrm{M}$ website views per year

At BMC, research is always in progress.

Learn more biomedcentral.com/submissions 